\title{
The impact of financial leverage on farm technical efficiency during periods of price instability
}

Article

Accepted Version

Gadanakis, Y., Stefani, G., Lombardi, G. and Tiberti, M. (2020) The impact of financial leverage on farm technical efficiency during periods of price instability. Agricultural Finance Review, 80 (1). pp. 1-21. ISSN 0002-1466 doi:

https://doi.org/10.1108/AFR-09-2018-0080 Available at https://centaur.reading.ac.uk/85728/

It is advisable to refer to the publisher's version if you intend to cite from the work. See Guidance on citing.

Published version at: https://www.emerald.com/insight/content/doi/10.1108/AFR-09-2018-0080/full/html

To link to this article DOI: http://dx.doi.org/10.1108/AFR-09-2018-0080

Publisher: Emerald

All outputs in CentAUR are protected by Intellectual Property Rights law, including copyright law. Copyright and IPR is retained by the creators or other copyright holders. Terms and conditions for use of this material are defined in the End User Agreement.

www.reading.ac.uk/centaur 
Central Archive at the University of Reading

Reading's research outputs online 


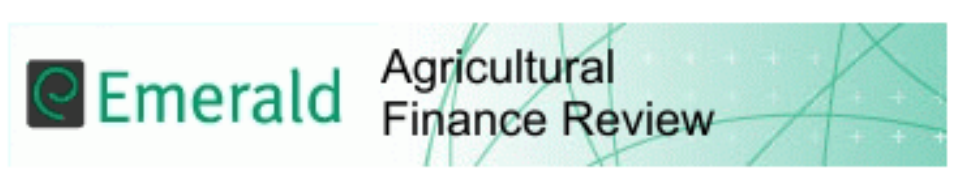

The impact of financial leverage on farm technical efficiency during periods of price instability

\begin{tabular}{|r|l|}
\hline Journal: & Agricultural Finance Review \\
\hline Manuscript ID & AFR-09-2018-0080.R3 \\
\hline Manuscript Type: & Research Article \\
\hline Keywords: & $\begin{array}{l}\text { financial leverage; technical efficiency; capital structure; expenditure } \\
\text { capacity; , adjustment theory, price instability }\end{array}$ \\
\hline \multicolumn{2}{|l}{} \\
\hline
\end{tabular}




\section{The impact of financial leverage on farm technical efficiency during periods of price instability}

\section{Purpose:}

The main purpose of this work is to provide empirical evidence on the relationship between capital structure and technical efficiency for Italian cereal farms during the 2008 - 2014 period. Emphasis is given in the understanding of the relationship between the level of financial leverage for cereal farms and their production performance.

\section{Methodology:}

The methods employed in this research article are based on non-parametric techniques in order to derive technical efficiency estimates for a sample of Italian cereal farms based on available Farm Accountancy Data Network data to explore in depth the relationship amongst the financial exposure of the sector and the capacity to utilise an efficient and effective production technology. Furthermore, subsidies are considered in the model as a nondiscretionary variable and therefore, as an input that farmers cannot directly influence within the production function. Hence, the non-discretionary Data Envelopment Analysis model is a more appropriate framework since it is not penalising farms at a lower level of Pillar I payments when benchmarked with farms that receive higher level of payments.

\section{Findings:}

The results show that significant improvements could be achieved for most of the farms in the sample by improving production and management practices. Furthermore, results provide an empirical support of the adjustment theory by showing a negative impact of debt to asset ratio to technical efficiency.

\section{Originality:}

This research article provides a first insight on the evolution of the Italian cereal farms debttechnical efficiency relationship in periods where high price instability has been observed.

Keywords: financial leverage; price instability; technical efficiency; capital structure; expenditure capacity;

Subject classification codes: Q12; Q14; D24 


\section{$1 \quad$ Introduction}

Farm capital structure may have contrasting effects on farm efficiency and investment behaviour as a strand of the farm efficiency literature has pointed out (Davidova and Latruffe, 2007, Barry and Robinson, 2001, Bojnec and Latruffe, 2013, Fertő et al., 2017). In particular, farmers' ability to choose the best available technology is restricted when capital structure negatively influences farm's financial performance (Mugera and Nyambane, 2015). However, the opposite is supported by Berger and Bonaccorsi di Patti (2006) where they suggest that the performance of a decision-making unit (farm) may also have an impact on the choice of capital structure. Hence, farms operating on the production efficiency frontier are more likely to realise higher return for a given capital structure, and these higher earnings could be used as bulwark against portfolio risk (Margaritis and Psillaki, 2010). Therefore, this will allow farms to substitute equity for debt when considering their capital structure (Margaritis and Psillaki, 2010). As Pedersen and Olsen (2013) suggest, the evaluation of the performance of farming systems would be more effective if the holistic approach to leverage proposed by Barry and Baker (1971) is considered. Hence, when both the external and internal credit constraints are considered. External funding at a farm level is used to cover both production costs and to finance investment plans (machinery, specialised equipment, and buildings) in order to enhance farm production performance (Lambert et al., 2005). The debt is necessary to maintain or improve farm productivity and competitiveness by adopting technological innovation needed to increase farm efficiency (Featherstone et al., 2005). At the same time, financial leverage may affect farm technical efficiency by influencing farm production decision (Margaritis and Psillaki, 2007, Lambert and Bayda, 2015). Allocative efficiency may be constrained by lower farm expenditure capacity (Färe et al., 1990, Rungsuriyawiboon and Hockmann, 2015). In this case, 
farms response may rely on reducing the necessary expenditures to maintain the production assets with negative consequences on farm productivity, growth and efficiency (Mugera and Nyambane, 2015). In addition, it is possible that the farmer is not adopting the needed strategic adjustments to maintain productivity, efficiency and competitiveness (Hughes et al., 1985). The latter became relevant after the outbreak of the financial crisis in 2008 where the size of loans for farming industries increased. In particular, financial leverage (gearing) in the European Union (EU) jumped from 14.1\% to $17.9 \%$ in 2008 indicating an increase in the size of debts (Pietola et al., 2011). Across the EU, the average farm debt increased from $€ 39,118$ in 2007 to $€ 50,022$ in 2008. Overall, total liabilities for both the EU-15 and the EU-N10 increased by approximately 50\% between 2004 and 2012 (European Commission, 2015). According to Petrick and Kloss (2013), the recent period of financial uncertainty (economic and financial crisis) came along with the following short comes due to the exposure of EU farmers to financial leverage: a) problems in the functionality of rural financial markets, b) reduction of farm incomes due to economic recession and c) lower demand for income elastic-food products. As stated by Hughes (1985) there are mainly three sources of financial stress for the farming sector: macroeconomic policies that in turn have an impact on prices and interest rates, sectoral policies that are often conceived to offset the former and individual management decisions. The period of $2008-2014$, was characterised from a surge in price volatility that affected European and world cereal markets as well as profitability and cash flow of cereal farms (Tadesse et al., 2014). In addition, reduced public budget and spending cuts in agricultural and rural policies further limited the potential of agricultural policies to offset market volatility. The riskier economic environment, would have a negative impact on farmers gross investment and therefore in the long-term competitiveness of the sector and the ability 
of the farmers to sustain operations and growth (technical efficiency) within a competitive agricultural market (Fertő et al., 2017, Bojnec and Latruffe, 2013, O'Toole and Hennessy, 2015). According to Petrick and Kloss (2013) the crisis of the banking sector in EU could potentially lead to a credit crunch for agricultural borrowers, by marrying the way that rural financial markets are functioning. Financial uncertainty could therefore lead to an increase of the level of debt over assets for the farming industry and hence threaten farm survival and potentially lead to the exit from the industry (Byrne et al., 2016, Musso and Schiavo, 2008). Furthermore, the period of $2008-2014$, was characterised from surge in price volatility that affected European and world cereal markets (Tadesse et al., 2014). Thus, contributing further to an environment of financial uncertainty, price instability and high economic risk for the farmers.

In the recent years since 2008, the economic recession and dwindling demand for income-elastic food products in Italy has caused a reduction on farm incomes and also a distortion in agricultural production due to limited access to credit for Italian farmers (Petrick Martin and Kloss, 2012). It is discussed in the literature that the relationship between capital structure and farm business performance is different from corporate firms due to characteristics ${ }^{1}$ that may result in different decision-making patterns at farm level and hence to capital structure (Zhengfei and Lansink, 2006). The uncertainty in the financial environment (due to food price instability, economic recession, and other exogenous parameters) has affected the Italian cereal market from 2008 onwards. Therefore, cereal farmers had to adopt their strategies and production methods to cope

\footnotetext{
${ }^{1}$ Family members participating in the production process and decision-making, business life cycle, legal form and liability status, government support in the form of agri-environmental payments etc.
} 
with exogenous parameters such as the 2010 drop in commodity prices, and hence maintain a healthy financial structure. According to Eurostat, the Italian cereal industry has been dramatically affected by the price crisis of 2008-2010 as the value of production fell by more than $30 \%$ in 2009 and fully recovered only in 2011 . In terms of comparison, the overall agricultural production decreased only by $8 \%$ in the same period. Noticeably, credit to agriculture became more and more important as the price instability unfolded. In 2014 the amount of bank loans to farms was about 20\% higher than in 2008 as illustrated by the data from Bank of Italy. In the same years, the share of short-term loans rose from $56 \%$ to $70 \%$ of the total amount, an indication that farmers resorted to loan financing mainly to deal with liquidity problems and economic stresses. Thus, the objective of this paper is to provide empirical evidence on the relationship between capital structure and technical efficiency for Italian cereal farms during the 2008 - 2014 period based on available data derived from the Farm Accountancy Data Network (FADN). Emphasis is given in the understanding of the relationship between the level of financial leverage for a sample of cereal farms and their production performance. The manuscript contributes into the relevant literature since it provides a first insight on the evolution of the Italian cereal farms debt-technical efficiency relationship in periods where uncertainty affected both the financial and commodity markets. The analysis offers a better understanding on the relationship between short, intermediate and long-term debt of the Italian cereal farms. The basic hypothesis tested here is that of the impact that external debt has on the ability of the cereal farmer to adjust production decision and, consequently on the technical efficiency of the decisionmaking unit (farm). In addition, it provides empirical evidence which helps to characterise the relationship between farm production and economic performance and the capital structure for the Italian cereal sector. The manuscript explores the Italian 
cereal sector as one of the most representative production sector of the Italian agricultural industry after specialist olives ${ }^{2}$. Furthermore, cereal farmers represent a significant percentage of the rural population in Italy with an average of 43ha UAA with smaller farmers (less than 10ha) facing difficulties in dealing with the complexity of the Italian agricultural sector (Salvioni et al., 2009) hence, more likely to be negatively affected in periods of price instability and financial uncertainty.

\section{Farm performance and capital structure}

Several theoretical explanations, often predicting contrasting evidence, have been put forward to explain the existence, if any, of a direct relationship between measures of indebtedness such as the leverage or Debt to Asset Ratio (DAR) and Technical Efficiency (TE) (Shaik, 2015). The relative theories, the direction of the relationship and the expected sign are summarised in Table 1. The DAR is in fact a leverage ratio which indicates how the agribusinesses have acquired their assets over a period of time. Together with other financial indicators it demonstrates the future economic sustainability of the agribusiness and the potential of the business to meet its current debt obligations as well as whether the agribusiness has the ability to pay a return on their investment. According to Zhengfei and Lansink (2006) financial indicators may not fully reveal the relationship between farm performance and managerial activities to improve performance when the effect of financial leverage is taken into consideration. Instead, Zhengfei and Lansink (2006) suggest that a measure of TE which is independent of market prices is more appropriate.

\footnotetext{
${ }^{2}$ Notably in terms of number of holdings
} 
The Fisher separation theorem states that, under perfectly functioning financial markets, financial and investment decisions are independent. Therefore, TE, which depends on investment decisions, should not be related to the way investments are financed (Lambert et al., 2005). However, in the context of agricultural investment, according to O'Toole et al. (2014), the financing constraints affect farmers' investment decisions through an excess reliance on internal farm funds for investment and farmer's investment strategies are based on the business fundamentals such as profitability. However, since the hypothesis of perfectly functioning financial markets is a rather restrictive one, especially in times of credit rationing, several alternative theoretical explanations have been advanced: free cash flow, agency cost and credit evaluation (Russell et al., 2017, Nadolnyak et al., 2017). The free cash flow model (Jensen and Meckling, 1976) posits that higher leverage reduces inefficiency by inducing stricter discipline on relaxed management which waste the abundant financial resources in selfserving objectives against the interest of the principal (the ownership). High debt ratios reduce the waste of cash by managers either through the need to generate cash to repay the debt or through the menace of liquidation. In the farm context where management and ownership is usually reunited in the same subject, the farmers are agents urged by lenders (principals) to exert greater effort to be able to repay the debt (Barry and Robinson, 2001).

The agency cost model (Margaritis and Psillaki, 2010) states a negative relationship between indebtedness and efficiency in a context of imperfect information as lenders transfer to borrowers the cost of monitoring thus, raising the costs of indebted farms. These additional costs are likely to reduce the TE of the affected farms in comparison with less indebted ones (Brewer and Featherstone, 2017). Both the agency cost and the free cash flow model hypothesise a causal relationship (even if with opposite sign) from 
indebtedness to technical efficiency. The credit evaluation hypothesis- also known as the efficiency risk hypothesis- postulates instead a reverse causation relationship where efficiency causes higher leverage as banks prefer borrowers with a low risk of financial distress (Parsons Chris and Titman Sheridan, 2011). Technical efficient firms may easily borrow as they are more likely to repay the debt (Demsetz, 1973, Berger and Bonaccorsi di Patti, 2006, Pedersen and Olsen, 2013). The empirical relevance of this mechanism should be more salient in contexts where loan applications are usually evaluated according to solvency, repayment capability, profitability, management ability and other financial and managerial variables ${ }^{3}$ (Margaritis and Psillaki, 2007). Conversely where loans are granted mainly on the availability of adequate collaterals, as it is the case in Italy, the hypothesis is less relevant (Davidova and Latruffe, 2007, Latruffe et al., 2008). Other hypothesis on the indebtedness and TE relationship are specific to the farm sector: the capital embodiment theory and the adjustment cost theory (Rungsuriyawiboon and Hockmann, 2015).

Table 1 Approximately here

Chavas and Aliber (1993) note that technical change in agriculture is often embodied in intermediate and long run assets such as machinery or new orchard varieties. If this is the case, then productivity improvements can be attained only by investing in the new

\footnotetext{
${ }^{3}$ Similarly, supply of credit to farmers has been found to positively correlate with observed changes in farm income. However, supply of operating ( short term) credit appears to be less reactive to changes in farm income with respect to supply of capital credit BARRY, P. J., BAKER, C. B. \& SANINT, L. R. 1981. Farmers' Credit Risks and Liquidity Management. American Journal of Agricultural Economics, 63, 216-227.
} 
technical assets which are often purchased and hence, resort farmers to being in debt (Sivertsson and Tell, 2015, Fertö et al., 2017) ${ }^{4}$. According to this theory more indebted farms should have a renovated technical capital and show higher technical efficiency. The adjustment theory was first proposed by Paul et al. (2000) in discussing the impact of the 1986 liberalization reform of the Agricultural Policy in New Zealand. According to this theory the financial constraints faced by indebted farms reduced their ability to adjust the new deregulated environment thus decreasing their efficiency. In this case a negative relationship between indebtedness and TE is assumed.

Hence, a variety of theories providing opposite predictions have been put forward to explain the DAR and TE relationship in the farm sector and beyond. Empirical evidence is mixed as far as it concerns the sign of the relationship while, exogeneity of debt is mainly assumed and not tested but for the case of Davidova and Latruffe (2007), as it is shown in Table 2

Table 2 Approximately here

Noticeably, a group of researchers decompose the overall DAR into the corresponding short term intermediate and long-term measures. In Chavas and Aliber (1993), Lambert et al. (2005) and Mugera and Nyambane (2015) where intermediate DAR is analysed it is found to have a positive relationship with TE supporting the capital embodiment theory. Results about overall and short-term DAR are mixed even if more negative signs are observed. A number of factors are likely to affect the observed evidence. First,

\footnotetext{
${ }^{4}$ Farm investment is not only constrained by long term credit availability. Also short term credit availability may prompt reaction to restore this source of liquidity by adjustments which affect technical efficiency such as sales of capital assets ibid.
} 
different methods are used to estimate the DAR and TE relationship either single stage stochastic frontier with simultaneous estimation of inefficiency model or two stage nonparametric DEA estimates followed by OLS or Tobit estimation of the inefficiency model. Moreover, different specification of both the SFA and DEA model select several alternative TE measures and covariates that can affect the estimate of the parameter of DAR. Ultimately the historical and institutional context in which the investigated farms operate is likely to impact on the DAR and TE relationship (Giannetti, 2003), noticeable examples being the Davidova and Latruffe (2007) and Catherine et al. (2000). This study will employ non-parametric techniques in order to derive TE estimates for a sample of Italian cereal farms to explore in depth the relationship amongst the financial exposure of the sector and the capacity to utilise an efficient and effective production technology. Considering that loans in the Italian agribusiness sector are granted based on collateral we assume that DAR impacts TE and hence, the credit evaluation hypothesis is not relevant in this context. However, we cannot dismiss a priori any of the other hypothesis put forward by the literature in regards to the sign of the relationship between DAR and TE, not least the adjustment theory. Indeed, since our sample is covering the period 2008 to 2014 we take into consideration two factors that have significantly contributed to the financial distress of Italian cereal farms (economic and commodity price instability). By promoting the understanding in regards to financial capital structure, and the provision of a new insight into the relationship between DAR and TE for the Italian cereal sector, this study is contributing to the 
development of relevant policy and fiscal interventions such as those envisaged by the recently proposed Agriculture Italian Guarantee Multiregional Platform (AIGMP) ${ }^{5}$.

\section{$3 \quad$ Methods and data}

Farm accountancy data for the empirical model was derived from Rete di Informazione Contabile Agricola (RICA), the Italian equivalent of FADN. The average size of the sample is about 11,000 farms per year between 2008 - 2014. The survey is performed by the former National Institute of Agricultural Economics and is responsible for collecting both financial and structural data for an individual farm. Although the RICA dataset is a partially rotating panel, for the purposes of this study is considered as a repeated cross-sectional sample. Cereal Farms amount to about $11 \%$ of the total sampled farms, a figure in line with the weight of cereal farms over total Italian agricultural holdings (Figure 1). With over 4 billion Euro of output in 2014, Italy was the third cereal producer in the European Union after France and Germany and just above UK and Poland.

\footnotetext{
${ }^{5}$ Instruments to optimise the use of capital aimed at facilitating access to credit and investment for small and medium sized farms and agribusinesses and hence improve the competitiveness of the Italian agri-food sector (https://en.cdp.it/Clients/Financial-Institutions/Instruments-To-Optimise-The-Use-Of-Capital/AgriPlatform/AGRI-Platform.kl)
} 
Figure 1: Number of holdings by main type of farming in Italy (2010 data)

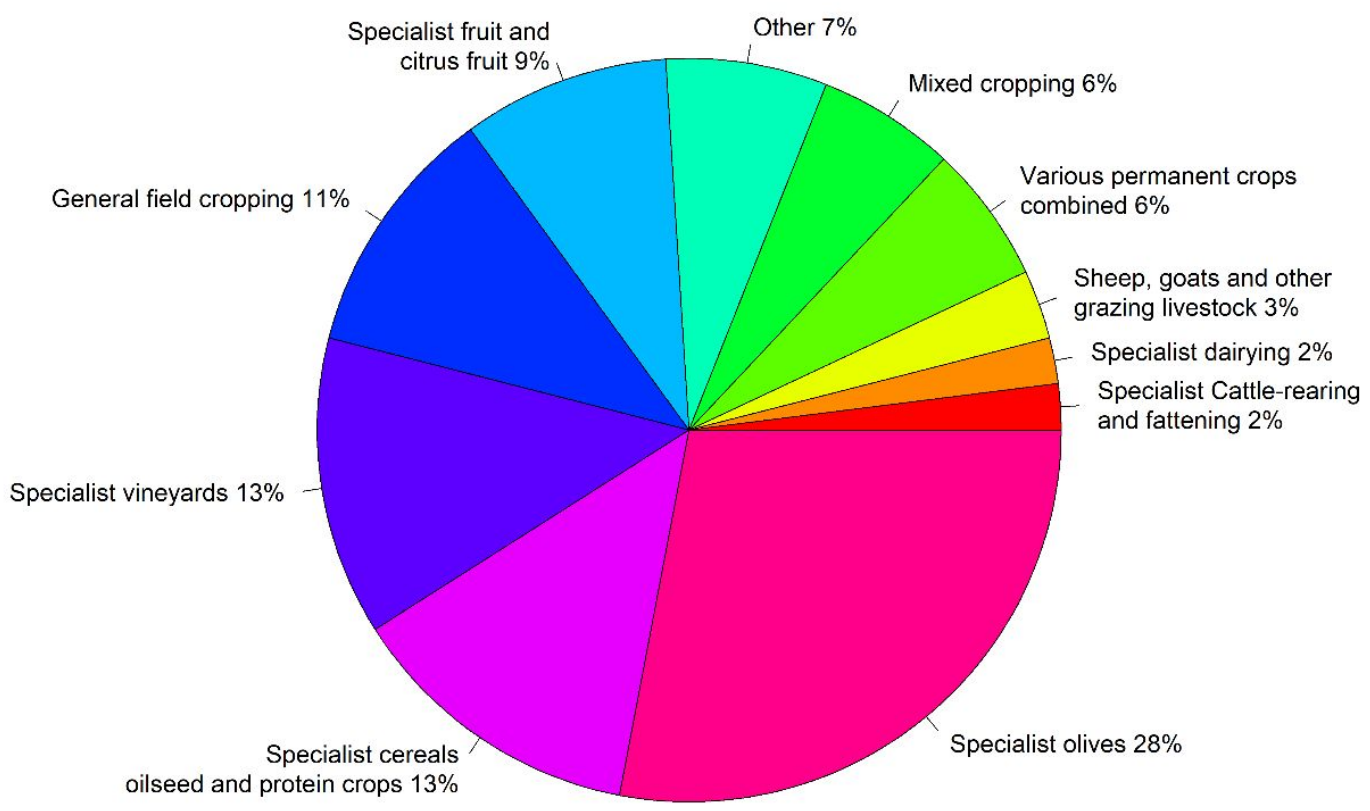

Source: EUROSTAT, Agricultural Census in Italy (2012)

Efficiency was estimated by carrying out an input-oriented sub-vector DEA model for each year ${ }^{6}$ of the sample and for each Italian macro-region ${ }^{7}$ under the constraint of constant returns to scale, thus obtaining total technical efficiency (TTE) estimates. The sub-vector (SBV) or non-discretionary DEA model has been used to account for the non-discretionary input of the CAP pillar one subsidies. It is assumed that farmers have no control over the amount of money that they receive and hence it is an input that they cannot directly influence within the production function. Therefore, a non-discretionary or SBV DEA model is used to evaluate input use efficiency estimates for cereal farms.

\footnotetext{
${ }^{6}$ For this reason we considered nominal and not deflated values.

${ }^{7}$ Italian macro-regions are defined as NUTS1 regions (North West, North East, Centre, South, Islands). To obtain 4 similarly sized sub samples we aggregated South Italy with the Islands resulting in 4 macro-regions.
} 
According to Gadanakis and Areal (2018) the SBV DEA model is more suitable to correctly assess the relative performance of each farm and therefore, account for the effect of the annual variation in amount of subsidies that the farmers receive in production efficiency. A detailed discussion and the results of a meta-analysis in regard to the treatment of subsidies in the estimation of technical efficiency is available in (Minviel and Latruffe, 2016). The importance of subsidies in technical efficiency (Latruffe et al., 2016) is not ignored by the model, instead, it is consider as a parameter that could have an impact on the efficiency outcome. Therefore, as a non-discretionary variable, subsidies are not used to penalise farms at a lower level of Pillar I payments when benchmarked in DEA with farms that receive higher level of payments. The DEA model includes two outputs (the value in Euros of the production of cereals and other agriculture products) and five inputs: the value in Euros of fixed capital costs (depreciation) and intermediate consumption, the total labour used per farm in Annual Working Units (AWU), the utilized agricultural area (UAA) in hectares and the Common Agricultural Policy 1st pillar subsidies received per farm (see Table 3 for variable definitions). Since DEA results are highly sensitive to the presence of outliers, we carried out a statistical method based on the algorithm proposed by Billor et al. (2000) for the detection of multiple outliers in multivariate data.

Table 3: Approximately here

Table 4 reports summary statistics for the variables included in the DEA model. The average value of Pillar I subsidies remains nearly constant over the period, as well as the amount of utilized agricultural area (UAA) and labour (Annual Working Units). However, the value of fixed capital costs slightly increases over the period under consideration, while the value of intermediate consumption remains constant over 2008- 
2010 and increases in 2011 and 2012 (22\% increase) reaching its peak in 2013 (38,000

$€)$. In regards to crop output we observe a significant variation in the period under consideration with the lowest values of crop output in 000s euros observed in 2009 $(42,000 €)$ and the highest in $2012(60,000 €)$. Other agricultural ouput is higher in the years prior to $2010(12,000 €)$ while it drops to an average of $7,000 €$ for the remaining of the period.

Table 4: Approximately here

To formalise the above let us assume that we observe a set of $\mathrm{n}$ farms and each farm $\mathrm{i}=\{1, . ., \mathrm{n}\}$ has a set of inputs and outputs representing multiple performance measures. Considering then that each farm i uses $\mathrm{J}(\mathrm{j}=1, \cdots, \mathrm{J})$ inputs, $\mathrm{x}_{\mathrm{j}}$ to produce $\mathrm{S}$ outputs $\mathrm{y}_{\mathrm{r}}$ $(\mathrm{r}=1, \cdots, \mathrm{S})$. The general form of an input-oriented DEA dual model (conventional (CNV) DEA model) with all inputs variable is as follows:

$$
\begin{gathered}
\min _{\theta, \lambda^{i}} \theta_{i C N V}^{\prime} \\
\text { s.t. } \quad \theta x_{j i}^{\prime} \geq \sum_{i=1}^{n} \lambda^{i} x_{j i} \\
y_{r i}^{\prime} \leq \sum_{i=1}^{n} \lambda^{i} y_{r i} \\
\lambda^{i} \geq 0
\end{gathered}
$$

Where, $\theta_{\mathrm{iCNV}}^{\prime}$, is a scalar, representing the efficiency score for each of the $\mathrm{n}$ farms estimated by the CNV DEA model. The estimate will satisfy the restriction $\theta_{\mathrm{i}} \leq 1$ with the value $\theta_{\mathrm{i}}=1$ indicating an efficient farm. This is because the ratio is formed relative to the Euclidean distance from the origin over the production possibility set. Also, in the above formulation we consider that there is a set of discretionary or variable inputs DI, DI $\subset\{1, \cdots, \mathrm{j}\}$ and a set of non-discretionary inputs NDI, NDI $=\{1, \cdots, F\}$ 
$\backslash \mathrm{DI}=\{\mathrm{h} \in\{1, \cdots \mathrm{J}\} \mid \mathrm{h} \notin \mathrm{DI}\}$ that cannot be adjusted or are held fixed at least in the short run. The combination of the DI and NDI variables therefore defines the technology set $\mathrm{P}_{\mathrm{SBV}}$ :

$$
\mathrm{P}_{\mathrm{SBV}}=\left\{\left(\mathrm{x}_{\mathrm{DIji}}, \mathrm{x}_{\mathrm{NDIji}}, \mathrm{y}_{\mathrm{ri}}\right) \mid \mathrm{x}_{\mathrm{DIji}} \text { and } \mathrm{x}_{\mathrm{NDIji}} \text { can produce } \mathrm{y}_{\mathrm{ri}}\right\}
$$

As suggested by Bogetoft and Otto (2010) in cases where DI and NDI variables exist, a traditional and popular variation of the Farrell (1957) procedure is used to solve the linear DEA programme with respect to the largest proportional reduction in the DI variables alone.

$$
\theta\left(\left(x_{D I j i}, x_{N D I j i}, y_{r i}\right) ; P\right)=\min _{\theta}\left\{\theta \mid\left(\theta x_{D I j i}, x_{N D I j i}, y_{r i}\right) \in P\right\}
$$

The linear DEA programme can therefore be modified as follows where only the DI variables are reduced. Thus, the input use DEA efficiency score when accounting pillar one subsidy variations for observation $\mathrm{x}^{\prime}, \theta^{\prime}$, is estimated by the following linear programming (LP) problem:

$$
\begin{gathered}
\min _{\theta, \lambda^{i}} \theta_{S B V}^{\prime} \\
\text { s.t. } \quad \theta x_{D I j i}^{\prime} \geq \sum_{i=1}^{n} \lambda^{i} x_{D I j i} \quad j \in D I \quad(i) \\
x_{N D I j i}^{\prime} \geq \sum_{i=1}^{n} \lambda^{i} x_{N D I j i} \quad j \in N D I \text { (ii) } \\
y_{r i}^{\prime} \leq \sum_{i=1}^{n} \lambda^{i} y_{r i} \\
\lambda^{i} \geq 0
\end{gathered}
$$

Where, $\mathrm{x}_{\mathrm{DIji}}$ is the $\mathrm{j}^{\text {th }}$ discretionary input for farm $\mathrm{i}, \mathrm{x}_{\mathrm{NDIji}}$ is the $\mathrm{j}^{\text {th }}$ non-discretionary input for farm $i$ and $y_{r i}$ is the $r_{\text {th }}$ output for farm $i, i=(1, \cdots n), j=(1, \cdots m)$ and $r=(1, \cdots s)$. The optimal value $\theta_{\mathrm{iSBV}}^{\prime}$ represents the SBV efficiency score for each farm and its values lie between 0 and 1 . This efficiency score indicates the degree to which a farm can reduce the use of its discretionary inputs without decreasing the level of outputs regarding the best performers or benchmarking farms in the sample. The first two 
constraints limit the proportional decrease in both discretionary (equation - 4(i)) and non-discretionary (equation - 4(ii)) inputs, when $\theta_{\mathrm{iSBV}}^{\prime}$ is minimised in relation to the input use achieved by the best observed technology. The third constraint ensures that the output generated by the $\mathrm{i}^{\text {th }}$ farm is less than that on the frontier. All three constraints ensure that the optimal solution belongs to the production possibility set. The final constraint expressed by the equation 4(iv), called also the convexity constraint, ensures the CRS assumption of the DEA SBV model (Cooper et al., 2006).

The DEA model under the Variable Returns to Scale assumption (the constrain iv, in equation (4) is now $\lambda^{\iota}=1$ ) decomposes technical efficiency into pure technical efficiency (PTE) and scale efficiency (SE) (Fare et al., 1993). Therefore, by estimating technical efficiency scores under assumptions of CRS $\left(\mathrm{TE}_{\mathrm{CRS}}\right)$ - known as a measure of overall technical efficiency (OTE) - and VRS (TE $\mathrm{VRS}_{\text {) }}$ one can measure the SE which measures the impact of scale size on the productivity of the farm. SE efficiency is therefore defined as follows:

$$
S E=\frac{T E_{C R S}}{T E_{V R S}}
$$

$S E$ can take values between 0 and 1 . When $S E=1 \mathrm{a}$ farm is operating at optimal scale size and otherwise if $S<1$. The information revealed by $S E$ is used to indicate potential benefits from adjusting farm size. Furthermore, $S E=\frac{T E_{C R S}}{T E_{V R S}}$ can be used to decompose $\mathrm{TE}_{\mathrm{CRS}}$ into two mutually exclusive and non-additive components, the pure technical efficiency (PTE) (estimated by the VRS specification) and $S E$.

$$
T E_{C R S}=T E_{V R S} * S E
$$

This allows an insight into the source of inefficiencies. The $T E_{V R S}$ specifies the possible efficiency improvement that can be achieved without altering the scale of operations. On the other hand, the $T E_{C R S}$ and $S E$ measures require the farm to adjust its scale of 
operation to improve efficiency and therefore should be viewed as long run measure that aims to reduce inputs for the long run improvement in efficiency.Furthermore, to investigate the impact of indebtedness on farm performance we have used the two stage semi-parametric model as it suggested in Simar and Wilson (2007).

Studies measuring productivity and efficiency using DEA to investigate the impact of environmental factors (a vector of $z$ variables that can either be continuous or discrete) at a second stage analysis have suffered from two problems. 1) Serial correlation among the DEA estimates and 2) Correlation of the inputs and outputs used in the first stage with second-stage environmental variables (Simar and Wilson, 2007). A solution to these problems consists of bootstrapping the results to obtain confidence intervals for the first stage productivity or efficiency scores (Simar and Wilson (1999, Simar and Wilson, 2007). The significance of the Simar and Wilson (2007) double bootstrap procedure derives from the bias corrected efficiency estimation of $\theta_{\mathrm{iSBV}}^{\prime}$ (estimated by expression (4)). These estimates are used as parameters in a truncated regression model. A detailed presentation of the double bootstrapped procedure and the Algorithm 1 used in this paper is available in Simar and Wilson (2007).

The truncated model to solve is of the form:

$$
\hat{\hat{y}}=z_{i} \beta+\varepsilon_{i}
$$

Where, $\hat{y}$ the bias corrected efficiency estimates, $z_{i}$ a vector of environmental variables (a vector of farm control variables), $\beta$ a vector of parameters to be estimated and $\varepsilon_{i}$ is the error term.

Table 5 reports summary statistics of the lagged leverage and control variables included in the regression model. Since the lagged leverage is considered in the analysis, data related to year 2008 will be dropped and the period $2009-2014$ will be considered in the truncated regression model. This will also have an impact into the number of observations 
(reduced/year) as it is demonstrated in Table 5. The control variables selection allows for testing the main management and structural characteristic of Italian cereal farms in relation to technical efficiency and financial performance. In order to capture any potential variation across the different Italian regions, regional dummies are introduced which divide the country into the North East (NE), North West (NW), Central, South and to the Island regions. The North West region is considered as the base category for the analysis since it is the most industrialised and developed region in the country (referred as the "Industrial Triangle" Milan, Turin Genoa). The regional dummies are used to explore differences in technical efficiency amongst farm businesses and therefore, identify areas where interventions are required in the form of policy support or extension services. Apart from regional dummies the analysis builds on variables which consider farmer and farm characteristics to provide further insight to the structural characteristics of the farm system and the relationship to technical efficiency. Farmer characteristics such as age and years in education of the farmer are considered to explore the relationship between managerial capabilities and technical efficiency. Hence, it is assumed that a younger farmer with more years in education would be keener to adopt contemporary methods of production and therefore be technical efficient. In addition, the role of gender in decision making and technical efficiency is explored. The variable associated to the share of rented land is testing the assumption that farmers with a higher percentage of rented land are more technical efficient as it is also the case of farm business with a high share of family labour. Furthermore, the share of tangible assets over total assets is considered in order to measure the impact of over capitalisation of the Italian cereal sector and it's impact to technical efficiency. In addition, a dummy for farms located in municipalities classified as less favoured areas (LFAs) was used to test the assumption of LFAs having limited access to resources and therefore being least technical efficient. 
Table 5: Approximately here

The (lagged) level of indebtedness or leverage is the main variable of interest. It has been constructed as the ratio of total liabilities over total assets. Although, the value for the DAR is very low, with small changes over the period 2009-2014, it is important to focus on this ratio since it will allow us to explore the financial sustainability of the cereal farms in Italy. The ratio of tangible to total assets shows a decline over the period 2009-2014, revealing a relative decrease in long-term investments. In addition, the analysis is considering the disaggregation of the DAR into the lagged long term and the short-term DAR. Hence, the second stage regression is considering two variants of the model. The assumption behind these two models is that the model with the lagged long term and the contemporaneous short-term DAR is exploring further the impact of shortterm DAR into technical efficiency as it is discussed in Barry et al. (1981). Hence, explore how the short-term DAR can demonstrate the use of short run credit as a reserve that provides liquidity to the business within an uncertain financial environment.

\section{$3 \quad$ Results and discussion}

A summary of the DEA SBV model results is presented in Table 6. The figures of mean efficiency represent the average potential equiproportional input reduction keeping constant the output, so smaller scores reveal greater inefficiency. An increase in the average efficiency score is observed in 2012 and is then maintained to similar levels for the remaining of the period under consideration. In addition, results indicate that efficiency is quite dispersed especially in the harvest periods of 2008, 2009 and 2010 ( $\mathrm{SD}=0.229,0.235$ and 0.227 respectively). These results suggest the need for 
improvements in production and management practices for the majority of the farms in the sample. In particular, it could be suggested that a $44 \%$ equiproportional reduction in the use of inputs is required for $2008,42 \%$ for $2009,40 \%$ for $2010,34 \%$ for $2011,30 \%$ for $2012,32 \%$ for 2013 and $30.2 \%$ 2014. In addition, it can be observed that the overall mean efficiency over the period of interest has increased to 0.698 in 2014 when compared to 0.561 in 2008. Similarly, the number of efficient farms on the frontier has also increased from $8.70 \%$ of the farms in the sample in 2008 to $13.97 \%$ for 2014 . However, to conclude on the progress of technical efficiency a dynamic efficiency model is required (Namiotko and Balezentis, 2017). It is important though to mention that we observe a positive shift of the number of farms towards the efficient frontier. Overall, a shift towards a more technical efficient status for the farms in the sample is observed since the percentage of farms with an efficient score less than 0.5 has decreased to $33.65 \%$ when compared to the 61.76 in 2008 . This is in line with Cechura et al. (2015) that have observed similar catching-up and falling behind processes for most of the EU cereal producers. In particular, technological change contributed positively towards technical efficiency of the Italian cereal sector and specifically for the years 2012 and 2014 while lower levels of technical efficiency have been observed for the years prior to 2010. This positive progress on technical efficiency for Italian cereal farms is also observed by Latruffe et al. (2016) where a positive association between subsidies and TE is observed and especially for the after decoupling period (2003 CAP reform). Moreover, Gitto (2017) has observed the same patterns for the different regions in Italy with North region being the most TE area in Italy when the agricultural sector is considered.

Table 6: Approximately here 
During the 2008 - 2014 period, on average $12 \%$ of the farms operated under constant returns to scale, hence indicating that a percentage of the farms in the sample is not required to adjust their scale of operations in order to improve efficiency in the long run. However, the majority of the farms is operating under a status of decreasing or increasing returns to scale and therefore, adjustment in the scale of operations is required in the long term. Table 7 presents the distribution of the efficiency estimates for both the pure technical efficiency (VRS DEA) and the scale efficiency (SE). The average pure technical efficiency between 2018 - 2014 is 0.72 and is higher than the overall technical efficiency as it is estimated by the SBV CRS DEA model (mean $\left.\mathrm{SBV}_{\text {eff }}=0.64\right)$. Hence, it indicates that Italian farms have a greater ability to catch up with technological changes when compared to their ability to allocate resources and adjust their management practices.

Table 7: Approximately here

In addition, the Fare et al. (1985) procedure (to define the status of increasing or decreasing returns to scale) concluded that most of the farms in the sample in average operate under increasing returns to scale $(61 \%)$, followed by farms operating under diminishing returns to scale $(25 \%)$. The latter could be used as an indicator of overcapitalisation or over mechanisation of the Italian cereal sector while the high percentage of increasing returns to scale is an indicator demonstrating the need for further improvements in the scale of operations and scale efficiency of the Italian cereal farms. The remaining of the sample operates under constant returns to scale. 
Table 8: Approximately here

The results of the model where the lagged long-term DAR and the contemporaneous short-term DAR are considered are summarised in Table 9. In both models, hence, either in the model where the lagged DAR is considered (Table 8), or where the lagged long term DAR and the contemporaneous short term DAR (Table 9) are considered, the negative impact of DAR in 2010 may be viewed as an empirical support of the adjustment theory posited by Paul et al. (2000). Indeed, the years 2009-2010 were characterized by a dramatic drop in the cereal prices $(-30 \%$ in 2009$)$ which was followed in 2010 by a timid increase by $6 \%$, still far below the 2007-2008 level. In 2011, prices were back to the peak of 2008 and stayed more stable for the following years. Thus, years 2009 and 2010 were particularly unfavourable for the cereal industry because of both the drop in output prices and the adverse terms of trade ${ }^{8}$. Therefore, financial exposure seems to be a source of inefficiency in time of price instability when farms need to face adjustment hardship to cope with rapidly changing price scenarios. The drop in cereal prices increases the financial constraints faced by indebted farms, thus reducing their ability to cope with higher financial stress and in turn decreasing their efficiency as is also indicated by the results of the SBV CRS DEA model (lower mean efficiency scores for 2008, 2009 and 2010 within the period). Furthermore, the negative sign observed for 2010 is also compatible with the agency cost theory of Jensen and Meckling (1976) as it is also discussed in Latruffe et al. (2016). Overall,

\footnotetext{
${ }^{8}$ It is worth noticing that an adverse term of trade arises again in 2014 when the output price index is still falling from its 2011 peak whereas the input price index reaches a peak
} 
across the period under consideration an inconsistency is observed in terms of the direction of the relationship between the DTA and TE for the Italian cereal farms which is also concluded in other studies (Latruffe et al., 2016, Davidova and Latruffe, 2007).

Table 9: Approximately here

Furthermore, tangible to total assets is another variable which in all years negatively impacts on efficiency. One possible reason for the negative impact of the ratio is the overcapitalization of Italian small farms which often are over mechanized. This is also in line with the finding of the returns to scale analysis where $25 \%$ of the farms in the sample operate under diminishing returns to scale.

Also farms with higher proportion of rented land are less efficient perhaps because of agency problems stemming from misalignment of farmer and landowner incentives, as posited by Giannakas et al. (2001), Hadley (2006) and Michler and Shively (2015). This in fact indicates that ownership of the land has a positive impact to technical efficiency since increases the incentives of the farmer to maximise effort and hence achieve higher production output (Michler and Shively, 2015, Heath, 2015). Another possible explanation may be found in reduced farmers' attitude towards long-term investment as effect of land tenure. As it has been expected farming systems based within LFAs will be less technical efficient when compared with the remaining farms in the sample with an exception of year 2009 where the coefficient is positive and statistically significant (0.05, p-value $<0.05)$. For LFAs in years $2010-2014$, the relationship is negative, though it is statistically significant only for the years 2011 and 2012. Finally, the coefficients of regional dummies reveal that cereal farms in North Italy (mainly NorthWestern regions and Central regions) are on average more efficient than in those located 
in the Island and Southern regions (Gitto, 2017). Especially for the Southern regions the results indicate that for the 2009 and 2010 the coefficient is negative and statistically significant $(-0.06$ and -0.12 respectively, $\mathrm{p}$-value $<0.01)$. However, the relationship sign is changing for the remaining of the period without though this being statistically significant. The years of education of conductor, a proxy for human capital, has a positive sign for all years in consideration but it is statistically significant only for the years 2009 and 2010. Furthermore, considering the gender of farm conductor is negative for the period under consideration but only statistically significant for the years 2009, 2010, 2012 and 2013. The results associated with the two age dummy variables of conductor provide a mixed outcome and it is difficult to draw a clear conclusion.

Considering the variable of interest i.e. DAR, the results confirm most of the findings in the literature regarding technical efficiency and its relationship to debt to asset ratio where a variation in the direction of the relationship is stated. The results contribute to the discussion regarding the best way to pursue structural adjustment in Italy which so far is left to market forces with dramatic surge in the percentage of rented UAA in Italy. Further and more targeted research is needed on this point. The lower TE estimates of Southern regions and especially in the years where price instability is observed (2009 and 2010) is of particular interest for policy makers since it confirms the overall need for further supporting agricultural systems based in the South of Italy in the form of investment subsidies and mechanisms that could contribute to the absorption of market price shocks. Indeed. the empirical results presented in Table 8 and Table 9 support the adjustment theory. Moreover, as it has been indicated by Gitto (2017) for Italian regions and as it has also been demonstrated by Latruffe et al. (2016) the positive shift of the farms to the frontier could be interpreted as an indication that decoupled payments have a positive influence on allocative efficiency. Therefore, it gives an indication of the 
direction that the support designed to facilitate access to credit and investment needs to take. This is extremely important when considering the small size of the Italian specialised cereal farms and their contribution to the rural economy.

\section{Conclusions}

In this paper, an SBV CRS DEA model was utilised to measure farm output efficiency of Italian cereal farms and to assess the relationship between farm capital structure and farm efficiency in the eve of the upsurge of cereal price instability in years $2008-2014$ and financial uncertainty. The empirical findings show that the relationship between farm efficiency and leverage is not statistically significant for all years but 2010 . Interestingly, 2009 is the very year when cereal prices dropped by almost $30 \%$ after the upsurge of 2007 - 2008 thus posing a significant stress on cereal farmers reflected to the technical efficiency of 2010. Similarly, to the policy induced price drop analysed by Paul et al. (2000) in New Zealand, results provide support for the adjustment theory as a possible explanation of the negative relationship between DAR and farm technical efficiency. According to this theory the financial constraints faced by indebted farms reduced their ability to adjust the dramatic deregulation of the agricultural sector in New Zealand, thus decreasing their efficiency. In the 2010 case a price shock caused a collapse of the output value as the one observed in New Zealand after the reform which in turn financially stressed especially indebted farms. As far as the authors know, no other study has highlighted the negative effect of such stress on the technical efficiency of Italian cereal farms. The paper contributes to the ongoing literature about the relationship of farm indebtedness and technical efficiency, a literature which posits a number of different testable propositions derived from alternative theoretical models. Every new empirical study which provides evidence against or in favour of a specific 
model contributes to the development of this strain of the agricultural finance theoretical debate.

In addition, our findings contribute to the debate on policy interventions aimed at mitigating the effect of price instability on farm economic sustainability. Underlining the relationship between financial constraints and farm flexibility to adapt to price instability, our results suggest the provision of additional support to increase the ability of farmers to cope with sharp price variations. Notably exploring the impact of a number of variables on TE we provide also suggestions on possible dimensions of the relative vulnerability of farms in times of high price instability. This type of information may prove relevant to policy makers when debating the focus and the direction of specific policy interventions for the agricultural sector (i.e. which regions in the country to focus, deciding on which age group and what other sociodemographic characteristics to consider, tenure status etc.). The paper presents a number of limitations that hint to further developments. The current DEA model is static. A dynamic model (a time variant dynamic model) could further explore the relationship between DAR and efficiency within the adjustment theory even if this would come at the cost of reduced external validity due to the rotated panel nature of the Italian FADN. Also the role of prices changes is only indirectly implied in the model by comparing results from different years, a further development may take into account this limit for instance using unit values as a covariate. Finally, the results indicate that the adjustment theory might be even more relevant for more capital-intensive agricultural sectors (dairy industry) beyond the cereal farming sector which has been the focus of this paper. However, the cereal sector is the one that experienced the largest rise in price instability in the considered period, thus remaining a valid case to study the relationship between DAR and TE despite its relatively low capital intensity. 


\section{References}

BARRY, P. J. \& BAKER, C. B. 1971. Reservation Prices on Credit Use: A Measure of Response to Uncertainty. American Journal of Agricultural Economics, 53, 222227.

BARRY, P. J., BAKER, C. B. \& SANINT, L. R. 1981. Farmers' Credit Risks and Liquidity Management. American Journal of Agricultural Economics, 63, 216227.

BARRY, P. J. \& ROBINSON, L. J. 2001. Agricultural finance: credit, credit constraints, and consequences. In: GARDNER, B. L. \& RAUSSER, G. C. (eds.) Handbook of Agricultural Economics: Agricultural Production. . Amsterdam: Elsevier Science B. V.

BERGER, A. N. \& BONACCORSI DI PATTI, E. 2006. Capital structure and firm performance: A new approach to testing agency theory and an application to the banking industry. Journal of Banking \& Finance, 30, 1065-1102.

BILLOR, N., HADI, A. S. \& VELLEMAN, P. F. 2000. BACON: blocked adaptive computationally efficient outlier nominators. Computational Statistics \& Data Analysis, 34, 279-298.

BOGETOFT, P. \& OTTO, L. 2010. Benchmarking with DEA, SFA, and R, New York, Springer.

BOJNEC, Š. \& LATRUFFE, L. 2013. Farm size, agricultural subsidies and farm performance in Slovenia. Land Use Policy, 32, 207-217.

BREWER, B. \& FEATHERSTONE, A. M. 2017. Agency cost of debt: evidence from Kansas farm operations. Agricultural Finance Review, 77, 111-124.

BYRNE, J. P., SPALIARA, M. E. \& TSOUKAS, S. 2016. Firm Survival, Uncertainty, and Financial Frictions: Is There a Financial Uncertainty Accelerator? Economic Inquiry, 54, 375-390.

CATHERINE, J. M. P., JOHNSTON, W. E. \& GERALD, A. G. F. 2000. Efficiency in New Zealand Sheep and Beef Farming: The Impacts of Regulatory Reform. The Review of Economics and Statistics, 82, 325-337.

CECHURA, L., HOCKMANN, H., MALÝ, M. \& ŽÁKOVÁ KROUPOVÁ, Z. 2015. Comparison of technology and technical efficiency in cereal production among EU Countries. AGRIS on-line Papers in Economics and Informatics, 7, 27-37.

CHAVAS, J.-P. \& ALIBER, M. 1993. An Analysis of Economic Efficiency in Agriculture: A Nonparametric Approach. Journal of Agricultural \& Resource Economics, 18.

COOPER, W., SEIFORD L. M \& TONE K. 2006. Data Envelopment Analysis: A Comprehensive Text with Models, Applications, References and DEA-Solver Software, Springer.

DAVIDOVA, S. \& LATRUFFE, L. 2007. Relationships between Technical Efficiency and Financial Management for Czech Republic Farms. Journal of Agricultural Economics, 58, 269-288.

DEMSETZ, H. 1973. Industry Structure, Market Rivalry, and Public Policy. The Journal of Law \& Economics, 16, 1-9.

EUROPEAN COMMISSION 2015. EU farm economics summary 2012. In: DG AGRICULTURE AND RURAL DEVELOPMENT, U. E. A. O. E. A. (ed.).

FÄRE, R., GROSSKOPF, S. \& LEE, H. 1990. A Nonparametric Approach to Expenditure-Constrained Profit Maximization. American Journal of Agricultural Economics, 72, 574-581. 
Färe, R., Grosskopf, S., \& Lovell, C. A. K. (2013). The Measurement of Efficiency of Production. The Measurement of Efficiency of Production. Dordrecht: Springer Netherlands. https://doi.org/10.1007/978-94-015-7721-2

FARE, R., GROSSKOPF, S. \& LOVELL, C. A. K. 1993. Production Frontiers, Cambridge, Cambridge University Press.

FARRELL, M. J. 1957. The Measurement of Productive Efficiency. Journal of the Royal Statistical Society. Series A (General), 120, 253-290.

FEATHERSTONE, A., ALLEN, M. F., GREGORY, A. I., WINTER, J. R. \& ASLIHAN, S. 2005. Farm financial structure. Agricultural finance review, 65, 97.

FERTÖ, I., BAKUCS, Z., BOJNEC, Š. \& LATRUFFE, L. 2017. East-west European farm investment behaviour - The role of financial constraints and public support. Spanish journal of agricultural research : SJAR, 15.

GADANAKIS, Y. \& AREAL, F. J. 2018. Accounting for rainfall and the length of growing season in technical efficiency analysis. Operational Research, 1-26.

GIANNAKAS, K., SCHONEY, R. \& TZOUVELEKAS, V. 2001. Technical efficiency, technological change and output growth of wheat farms in Saskatchewan. Canadian Journal of Agricultural Economics/Revue canadienne d'agroeconomie, 49, 135-152.

GIANNETTI, M. 2003. Do better institutions mitigate agency problems? Evidence from corporate finance choices. Journal of Financial and Quantitative Analysis, 38, $185-212$.

GITTO, S. 2017. Efficiency change, technological change and capital accumulation in Italian regions: a sectoral study. International Review of Applied Economics, 31, 191-207.

HADLEY, D. 2006. Patterns in Technical Efficiency and Technical Change at the Farm-level in England and Wales, 1982-2002. Journal of Agricultural Economics, 57, 81-100.

HEATH, H. 2015. Considering Technical and Allocative Efficiency in the Inverse Farm Size-Productivity Relationship. Journal of Agricultural Economics, 66, 442-469.

HUGHES, W., RICHARDSON, J. W. \& RISTER, M. E. 1985. Effects of Sustained Financial Stress on the Financial Structure and Performance of the Farm Sector. American Journal of Agricultural Economics, 67, 1116-1122.

JENSEN, M. C. \& MECKLING, W. H. 1976. Theory of the firm: Managerial behavior, agency costs and ownership structure. Journal of financial economics, 3, 305-360.

LAMBERT, D., DAVID, K. L. \& VOLODYMYR, V. B. 2005. The Impacts of Farm Financial Structure on Production Efficiency. Journal of agricultural and applied economics, 37, 277.

LAMBERT, D. K. \& BAYDA, V. V. 2015. The Impacts of Farm Financial Structure on Production Efficiency. Journal of Agricultural and Applied Economics, 37, 277289.

LATRUFFE, L., BRAVO-URETA, B. E., CARPENTIER, A. \& DESJEUX, Y. 2016. Subsidies and technical efficiency in agriculture: evidence from European dairy farms. American journal of agricultural economics, Online first.

LATRUFFE, L., DAVIDOVA, S. \& BALCOMBE, K. 2008. Application of a double bootstrap to investigation of determinants of technical efficiency of farms in Central Europe. Journal of Productivity Analysis, 29, 183-191.

MARGARITIS, D. \& PSILLAKI, M. 2007. Capital Structure and Firm Efficiency. Journal of Business Finance \& Accounting, 34, 1447-1469. 
MARGARITIS, D. \& PSILLAKI, M. 2010. Capital structure, equity ownership and firm performance. Journal of Banking \& Finance, 34, 621-632.

MICHLER, J. D. \& SHIVELY, G. E. 2015. Land Tenure, Tenure Security and Farm Efficiency: Panel Evidence from the Philippines. Journal of Agricultural Economics, 66, 155-169.

MINVIEL, J. J. \& LATRUFFE, L. 2016. Effect of public subsidies on farm technical efficiency: a meta-analysis of empirical results. Applied economics, 49, 213-226.

MUGERA, A. W. \& NYAMBANE, G. G. 2015. Impact of debt structure on production efficiency and financial performance of Broadacre farms in Western Australia. Australian Journal of Agricultural and Resource Economics, 59, 208-224.

MUSSO, P. \& SCHIAVO, S. 2008. The impact of financial constraints on firm survival and growth. Journal of Evolutionary Economics, 18, 135-149.

NADOLNYAK, D., SHEN, X. \& HARTARSKA, V. 2017. Farm income and output and lending by the farm credit system. Agricultural Finance Review, 77, 125-136.

NAMIOTKO, V. \& BALEZENTIS, T. 2017. Dynamic Efficiency under Investment Spikes in Lithuanian Cereal and Dairy Farms. Economics \& Sociology, 10, 33-46.

O'TOOLE, C. M., NEWMAN, C. \& HENNESSY, T. 2014. Financing Constraints and Agricultural Investment: Effects of the Irish Financial Crisis. Journal of Agricultural Economics, 65, 152-176.

O'TOOLE, C. \& HENNESSY, T. 2015. Do decoupled payments affect investment financing constraints? Evidence from Irish agriculture. Food Policy, 56, 67-75.

PAPKE, L. E. \& WOOLDRIDGE, J. 1993. Econometric methods for fractional response variables with an application to $401(\mathrm{k})$ plan participation rates. National Bureau of Economic Research Cambridge, Mass., USA.

PARSONS CHRIS \& TITMAN SHERIDAN 2011. Capital Structure and Corporate Strategy. In: ECKBO, B. E. (ed.) Handbook of Empirical Corporate Finance: Empirical Corporate Finance. Elsevier Science.

PAUL, C. J. M., JOHNSTON, W. E. \& FRENGLEY, G. A. 2000. Efficiency in New Zealand sheep and beef farming: the impacts of regulatory reform. Review of Economics and Statistics, 82, 325-337.

PEDERSEN, M. F. \& OLSEN, J. V. 2013. Measuring credit capacity on Danish farms using DEA. Agricultural Finance Review, 73, 393-412.

PETRICK, M. \& KLOSS, M. 2013. Exposure of EU Farmers to the Financial Crisis. Choices, 28, 1-6.

PETRICK MARTIN \& KLOSS, M. 2012. Working paper: Drivers of agricultural capital productivity in selected EU member states. In: FACTOR MARKETS COORDINATION: CENTRE FOR EUROPEAN POLICY STUDIES (CEPS) (ed.) Comparative analysis of Factor Markets for agriculture across the member states.

PIETOLA, K., MYYRÄ, S. \& HEIKKILÄ, A.-M. 2011. The penetration of financial instability in agricultural credit and leveraging. Factor Markets Working Papers.

RUNGSURIYAWIBOON, S. \& HOCKMANN, H. 2015. Adjustment costs and efficiency in Polish agriculture: a dynamic efficiency approach. Journal of Productivity Analysis, 44, 51-68.

RUSSELL, L. A., BRIGGEMAN, B. C. \& FEATHERSTONE, A. M. 2017. Financial leverage and agency costs in agricultural cooperatives. Agricultural Finance Review, 77, 312-323.

Salvioni C, Esposito L, Henke R, Rondinelli V (2009) Diversification strategies in small farms in Italy, 111 EAAE-IAAE seminar 'small farms: decline or persistence' University of Kent, Canterbury, UK 26th-27th June 
SHAIK, S. 2015. Impact of liquidity risk on variations in efficiency and productivity: A panel gamma simulated maximum likelihood estimation. European Journal of Operational Research, 245, 463-469.

SIMAR, L. \& WILSON, P. W. 1999. Estimating and bootstrapping Malmquist indices. European Journal of Operational Research, 115, 459-471.

SIMAR, L. \& WILSON, P. W. 2007. Estimation and inference in two-stage, semiparametric models of production processes. Journal of Econometrics, 136, 31-64.

SIVERTSSON, O. \& TELL, J. 2015. Barriers to Business Model Innovation in Swedish Agriculture. Sustainability, 7, 1957.

TADESSE, G., ALGIERI, B., KALKUHL, M. \& VON BRAUN, J. 2014. Drivers and triggers of international food price spikes and volatility. Food Policy, 47, 117128.

ZHENGFEI, G. \& LANSINK, A. O. 2006. The Source of Productivity Growth in Dutch Agriculture: A Perspective from Finance. American Journal of Agricultural Economics, 88, 644-656. 


\section{Manuscript ID AFR-09-2018-0080, entitled "The impact of financial leverage on farms capacity to react in market shocks."}

Table 1: Theorethical findings on the relationship between Debt to Asset Ratio (DAR) and Technical Efficiency.

\begin{tabular}{|c|c|c|c|}
\hline Theory & $\begin{array}{l}\text { Direction of the } \\
\text { Relationship }\end{array}$ & $\begin{array}{l}\text { Expected sign of } \\
\text { Relationship }\end{array}$ & Reference \\
\hline Fisher separation theorem & - & - & Lambert et al., 2005 \\
\hline Free cash flow model & $\mathrm{DAR} \rightarrow \mathrm{TE}$ & Positive & Jensen and Meckling, 1976) \\
\hline Agency cost model & $\mathrm{DAR} \rightarrow \mathrm{TE}$ & Negative & Margaritis and Psillaki, 2010 \\
\hline Credit evaluation hypothesis & $\mathrm{TE} \rightarrow \mathrm{DAR}$ & Positive & $\begin{array}{l}\text { Berger and Bonaccorsi di Patti } \\
\text { (2006) }\end{array}$ \\
\hline Capital embodiment theory & $\mathrm{DAR} \rightarrow \mathrm{TE}$ & Positive & Chavas and Aliber (1993b) \\
\hline Adjustment theory & $\mathrm{DAR} \rightarrow \mathrm{TE}$ & Negative & Paul et al. (2000) \\
\hline
\end{tabular}

Table 2: Empirical findings on the relationship between Debt to Asset Ratio (DAR) and Technical Efficiency.

\begin{tabular}{|c|c|c|c|}
\hline Authors & Country & Endogeneity of debt & Sign of relationship \\
\hline D. Lambert et al. (2005) & USA & (assumed) & $\begin{array}{l}\text { - (short term DAR) } \\
+ \text { (intermediate DAR) }\end{array}$ \\
\hline $\begin{array}{r}\text { A.W. Mugera and Nyambane } \\
\text { (2015) }\end{array}$ & Australia & (assumed) & $\begin{array}{l}+(\text { short term DAR) } \\
\text { ns (long term DAR) }\end{array}$ \\
\hline Chavas and Aliber (1993a) & USA & (assumed) & $\begin{array}{c}\text { ns (short term DAR) } \\
+(\text { intermediate DAR }) \\
+(\text { long term DAR })\end{array}$ \\
\hline Hadley (2006) & UK & (assumed) & $-(D A R)$ \\
\hline Davidova and Latruffe (2007) & Czech Rep. & $\begin{array}{c}\text { (tested and rejected for } \\
\text { private farms) }\end{array}$ & - (DAR) depending on farm type \\
\hline Latruffe, Bravo-Ureta, & $\begin{array}{l}\text { Denmark \& } \\
\text { Poland }\end{array}$ & (account for endogeneity) & - $(D A R)$ \\
\hline Carpentier, and Desjeux (2016) & Spain & & $+(D A R)$ \\
\hline \multirow[t]{2}{*}{$\begin{array}{r}\text { Giannakas, Schoney, and } \\
\text { Tzouvelekas (2001) }\end{array}$} & Canada & (assumed) & $+(D A R)$ \\
\hline & New Zealand & (assumed) & - (DAR) \\
\hline
\end{tabular}


Table 3: Definition of variables used in the DEA sub-vector model

\begin{tabular}{l|l} 
Variable & Definition \\
\hline \multirow{3}{*}{ Crop Output (000€) } & $\begin{array}{l}\text { Total crop output ( sales+change in stocks+ farmhouse consumption) net of } \\
\text { subsidies, of cereal crops }\end{array}$ \\
Other Agricultural Output (000€) & Total agricultural output net of subsidies - crop output \\
Pillar I subsidies (000€) & Subsidies ( CAP first pillar) excludinged investment subsidies \\
Labour (AWU) & Number of total Annual Work Units \\
UAA H(ha) & Utilized Agricultural Area in hectares \\
Intermediate consumption (000€) & Total intermediate consumption ( total specific costs + total farming overheads) \\
Fixed capital costs (000€) & Depreciation
\end{tabular}


Table 4: Descriptive statistics of outputs and inputs used in the DEA sub-vector model

\begin{tabular}{|c|c|c|c|c|c|c|c|c|c|c|c|c|c|c|c|}
\hline & & 2008 & & 2009 & & 2010 & & 2011 & & 2012 & & 2013 & & 2014 & \\
\hline & Mean & & S.D. & Mean & S.D. & Mean & S.D. & Mean & S.D. & Mean & S.D. & Mean & S.D. & Mean & S.D. \\
\hline Crop Output (000€) & & 46 & 73 & 42 & 74 & 51 & 71 & 58 & 78 & 60 & 75 & 56 & 76 & 58 & 86 \\
\hline other Agricultural Output (000€) & & 12 & 21 & 11 & 21 & 7 & 13 & 8 & 15 & 6 & 11 & 7 & 13 & 7 & 14 \\
\hline Pillar I subsidies (000€) & & 19 & 29 & 20 & 29 & 20 & 32 & 21 & 31 & 20 & 29 & 21 & 32 & 21 & 37 \\
\hline Labour (AWU) & & 1.1 & 0.8 & 1.1 & 0.8 & 1.1 & 0.7 & 1.2 & 0.8 & 1.2 & 0.8 & 1.2 & 0.8 & 1.2 & 0.8 \\
\hline UAA (haHa) & & 43.8 & 53.9 & 45 & 51.6 & 43.4 & 49.3 & 44.2 & 49.7 & 42.9 & 45.5 & 43.4 & 48.2 & 43.1 & 47.7 \\
\hline Intermediate consumption (000€) & & 32 & 39 & 31 & 38 & 31 & 43 & 37 & 47 & 38 & 46 & 38 & 48 & 38 & 50 \\
\hline Fixed capital costs (000€) & & 7 & 10 & 7 & 11 & 6 & 11 & 6 & 11 & 6 & 10 & 6 & 11 & 6 & 12 \\
\hline Number of observations & & 1517 & & 1332 & & 1292 & & 1292 & & 1265 & & 1229 & & 1052 & \\
\hline
\end{tabular}


Table 5: Summary statistics of the control variables included in the regression model

\begin{tabular}{|c|c|c|c|c|c|c|c|c|c|c|c|c|}
\hline & \multicolumn{2}{|c|}{2009} & \multicolumn{2}{|c|}{2010} & \multicolumn{2}{|c|}{2011} & \multicolumn{2}{|c|}{2012} & \multicolumn{2}{|c|}{2013} & \multicolumn{2}{|c|}{2014} \\
\hline & Mean & S.D. & Mean & S.D. & Mean & S.D. & Mean & S.D. & Mean & S.D. & Mean & S.D. \\
\hline CRS eff. scores & 0.57 & 0.23 & 0.60 & 0.22 & 0.67 & 0.19 & 0.69 & 0.19 & 0.68 & 0.19 & 0.69 & 0.19 \\
\hline Lagged Debt to asset ratio (DAR) & 0.02 & 0.1 & 0.02 & 0.09 & 0.02 & 0.12 & 0.01 & 0.09 & 0.01 & 0.08 & 0.02 & 0.11 \\
\hline Lagged Long term DAR & 0.00 & 0.04 & 0.00 & 0.04 & 0.00 & 0.02 & 0.00 & 0.01 & 0.00 & 0.03 & 0.00 & 0.03 \\
\hline Contemporaneous Short_term DAR & 0.02 & 0.10 & 0.02 & 0.12 & 0.01 & 0.09 & 0.01 & 0.08 & 0.01 & 0.09 & 0.01 & 0.09 \\
\hline Share tangible assets & 0.79 & 0.24 & 0.73 & 0.27 & 0.73 & 0.26 & 0.69 & 0.27 & 0.67 & 0.28 & 0.64 & 0.29 \\
\hline Share farm labour & 0.94 & 0.17 & 0.95 & 0.16 & 0.95 & 0.16 & 0.95 & 0.16 & 0.95 & 0.14 & 0.95 & 0.14 \\
\hline Education in years & 8.13 & 3.78 & 8.72 & 3.53 & 8.69 & 3.65 & 8.75 & 3.53 & 8.75 & 3.39 & 9.07 & 3.34 \\
\hline Age (Years) & 57.91 & 14.24 & 57.83 & 14.31 & 58.75 & 13.89 & 59.23 & 13.95 & 59.55 & 13.90 & 58.60 & 13.41 \\
\hline Share rented land (\%) & 0.37 & 0.42 & 0.39 & 0.42 & 0.35 & 0.41 & 0.37 & 0.41 & 0.38 & 0.42 & 0.42 & 0.41 \\
\hline Young $\overline{(\%)}$ & $11 \%$ & & $11 \%$ & & $8 \%$ & & $7 \%$ & & $7 \%$ & & $7 \%$ & \\
\hline Elder (\%) & $31 \%$ & & $32 \%$ & & $34 \%$ & & $34 \%$ & & $35 \%$ & & $33 \%$ & \\
\hline Female $\overline{(\%)}$ & $16 \%$ & & $16 \%$ & & $17 \%$ & & $17 \%$ & & $16 \%$ & & $16 \%$ & \\
\hline Farms in total LFA $(\%)$ & $27 \%$ & & $26 \%$ & & $27 \%$ & & $26 \%$ & & $28 \%$ & & $23 \%$ & \\
\hline Region NW(\%) & $34 \%$ & & $41 \%$ & & $32 \%$ & & $34 \%$ & & $33 \%$ & & $41 \%$ & \\
\hline Region $N E \overline{(\%)}$ & $24 \%$ & & $20 \%$ & & $24 \%$ & & $22 \%$ & & $22 \%$ & & $23 \%$ & \\
\hline Region Central(\%) & $20 \%$ & & $18 \%$ & & $19 \%$ & & $21 \%$ & & $22 \%$ & & $16 \%$ & \\
\hline Region South $(\%)$ & $18 \%$ & & $19 \%$ & & $23 \%$ & & $21 \%$ & & $21 \%$ & & $18 \%$ & \\
\hline Region Islands (\%) & $3 \%$ & & $2 \%$ & & $2 \%$ & & $2 \%$ & & $2 \%$ & & $2 \%$ & \\
\hline Number of observations & 1002 & & 741 & & 953 & & 897 & & 899 & & 657 & \\
\hline
\end{tabular}

Note: Standard output calculated according to Regulation (EC) No 1242/2008. Region NW includes Piedmont, Lombardy, Liguria and Aosta Valley; region NE includes Veneto, Emilia Romagna, Trentino Sud Tirol, Friuli Veneza Giulia and Emilia Romagna; Region Central Includes Tuscany, Umbria, Marche and Lazio, South includes Abruzzi, Molise Apulia, Campania, Basilicata, Calabria; Island includes Sicily and Sardinia. 
Table 6: Summary table of efficiency scores derived from an input oriented non-discretionary CRS DEA model

\begin{tabular}{|c|c|c|c|c|c|c|c|}
\hline \multirow[t]{2}{*}{ Efficiency Distribution } & 2008 & 2009 & 2010 & 2011 & 2012 & 2013 & 2014 \\
\hline & \multicolumn{7}{|c|}{$\%$ of Farms } \\
\hline$E f f<0.5$ & $43.90 \%$ & $43.99 \%$ & $37.49 \%$ & $22.91 \%$ & $14.62 \%$ & $18.39 \%$ & $17.78 \%$ \\
\hline $0.5 \leq$ Eff $<0.6$ & $17.86 \%$ & $15.54 \%$ & $18.40 \%$ & $18.50 \%$ & $17.63 \%$ & $18.88 \%$ & $15.87 \%$ \\
\hline $0.6 \leq$ Eff $<0.7$ & $12.79 \%$ & $11.41 \%$ & $12.47 \%$ & $17.26 \%$ & $22.92 \%$ & $19.85 \%$ & $17.68 \%$ \\
\hline $0.7 \leq E f f<0.8$ & $8.44 \%$ & $8.11 \%$ & $9.16 \%$ & $16.02 \%$ & $15.18 \%$ & $14.81 \%$ & $16.16 \%$ \\
\hline $0.8 \leq E f f<0.9$ & $5.47 \%$ & $6.16 \%$ & $8.01 \%$ & $10.29 \%$ & $10.12 \%$ & $9.60 \%$ & $11.60 \%$ \\
\hline $0.9 \leq E f f<1$ & $2.83 \%$ & $3.60 \%$ & $4.31 \%$ & $4.33 \%$ & $5.93 \%$ & $5.70 \%$ & $6.94 \%$ \\
\hline Efficiency = 1 & $8.70 \%$ & $11.19 \%$ & $10.16 \%$ & $10.68 \%$ & $13.60 \%$ & $12.77 \%$ & $13.97 \%$ \\
\hline Mean Efficiency & 0.561 & 0.580 & 0.601 & 0.661 & 0.700 & 0.682 & 0.698 \\
\hline SD Efficiency & 0.229 & 0.235 & 0.227 & 0.198 & 0.188 & 0.196 & 0.203 \\
\hline Number of Farms & 1517 & 1332 & 1299 & 1292 & 1265 & 1229 & 1052 \\
\hline
\end{tabular}

Note: outliers and observations with either negative outputs or negative inputs dropped 
Table 7: Distribution of the overal technical efficiency decomposition into pure technical and scale efficiency expressed as percentages

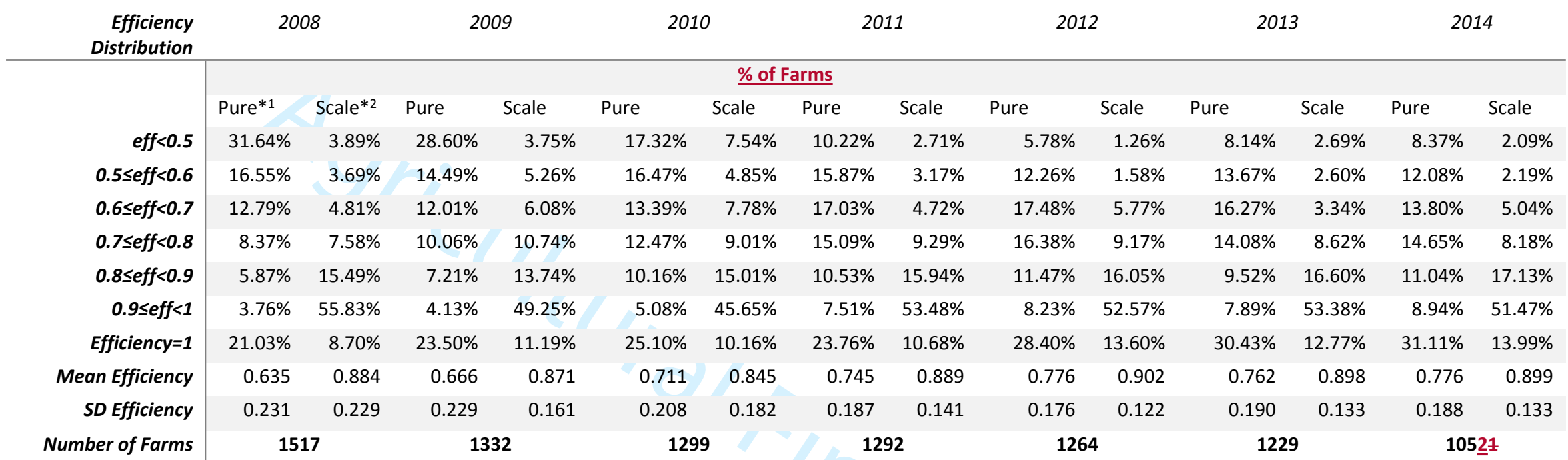

${ }^{* 1}=$ Pure technical efficiency, ${ }^{* 2}=$ Scale efficiency 
Table 8: Exploring the relationship between technical efficiency of Italian arable farms with the lagged DAR and other farm and farm management characteristics

\begin{tabular}{|c|c|c|c|c|c|c|c|c|c|c|c|c|}
\hline & 2009 & & 2010 & & 2011 & & 2012 & & 2013 & & 2014 & \\
\hline & Coef. & S.E. & Coef. & S.E. & Coef. & S.E. & Coef. & S.E. & Coef. & S.E. & Coef. & S.E. \\
\hline Lagged DAR & -0.05 & 0.07 & $-0.16^{* *}$ & 0.08 & 0.09 & 0.07 & 0.01 & 0.09 & 0.03 & 0.07 & -0.10 & 0.07 \\
\hline Share tangible assets & $-0.26 * * *$ & 0.03 & $-0.16^{* * *}$ & 0.04 & $-0.13 * * *$ & 0.03 & $-0.16 * * *$ & 0.03 & $-0.13 * * *$ & 0.03 & $-0.21 * * *$ & 0.04 \\
\hline Share farm labour & $-0.13 * * *$ & 0.04 & -0.05 & 0.05 & $-0.16 * * *$ & 0.04 & $-0.13 * * *$ & 0.04 & $-0.12 * * *$ & 0.05 & $-0.13 * *$ & 0.05 \\
\hline Education in years & $0.03 * * *$ & 0.01 & $0.03 *$ & 0.01 & 0.02 & 0.01 & 0.01 & 0.01 & 0.00 & 0.01 & 0.00 & 0.02 \\
\hline$\underline{\text { Share rented land }}$ & $\underline{\underline{-0.04 * *}}$ & $\underline{\underline{0.02}}$ & $\underline{\underline{-0.06 * * *}}$ & $\underline{\underline{0.02}}$ & $\underline{\underline{-0.01}}$ & $\underline{\underline{0.02}}$ & $\underline{\underline{-0.05 * * *}}$ & $\underline{\underline{0.02}}$ & $\underline{\underline{-0.04 *}}$ & $\underline{\underline{0.02}}$ & $\underline{\underline{-0.06 * *}}$ & $\underline{\underline{0.03}}$ \\
\hline Young & -0.02 & 0.02 & 0.01 & 0.03 & -0.01 & 0.02 & -0.01 & 0.02 & 0.00 & 0.02 & $0.05^{*}$ & 0.03 \\
\hline Elder & -0.02 & 0.01 & 0.00 & 0.02 & $0.02 *$ & 0.01 & -0.01 & 0.01 & $-0.05 * * *$ & 0.01 & -0.02 & 0.02 \\
\hline Female & $-0.06 * * *$ & 0.02 & $-0.06 * * *$ & 0.02 & -0.02 & 0.02 & $-0.03 * *$ & 0.02 & $-0.03 * *$ & 0.02 & -0.02 & 0.02 \\
\hline Share rented land & $-0.04 * *$ & $\theta .02$ & $-0.06 * * *$ & $\theta .02$ & -0.01 & $\theta .02$ & $-0.05 * * *$ & $\theta .02$ & $-0.04 *$ & $\theta .02$ & $-0.06 * *$ & 0.03 \\
\hline Farm in total LFA & $0.05^{* *}$ & 0.02 & -0.02 & 0.02 & $-0.04 * *$ & 0.02 & $-0.04 *$ & 0.02 & -0.03 & 0.02 & -0.01 & 0.02 \\
\hline Region $N E$ & $0.23^{* * *}$ & 0.02 & $0.16^{* * *}$ & 0.02 & $0.14 * * *$ & 0.02 & $0.07 * * *$ & 0.02 & $0.08^{* * *}$ & 0.02 & $0.22 * * *$ & 0.02 \\
\hline Region Central & $0.06^{* * *}$ & 0.02 & $0.04 *$ & 0.02 & 0.03 & 0.02 & $0.06^{* * *}$ & 0.02 & $0.06^{* * *}$ & 0.02 & $0.10 * * *$ & 0.03 \\
\hline Region South & $-0.06^{* *}$ & 0.02 & $-0.12 * * *$ & 0.03 & $0.05 * * *$ & 0.02 & $0.03 *$ & 0.02 & $0.04 *$ & 0.02 & $0.10^{* * *}$ & 0.03 \\
\hline Region Islands & 0.06 & 0.04 & $-0.16^{* * *}$ & 0.06 & -0.02 & 0.04 & -0.02 & 0.05 & 0.00 & 0.04 & -0.02 & 0.05 \\
\hline Constant & $0.76^{* * *}$ & 0.05 & $0.70 * * *$ & 0.07 & $0.81^{* * *}$ & 0.05 & $0.87 * * *$ & 0.06 & $0.85^{* * *}$ & 0.06 & $0.86^{* * *}$ & 0.09 \\
\hline$N$ & 1002 & & 741 & & 953 & & 897 & & 899 & & 657 & \\
\hline Log Likelihood & 348 & & 253 & & 388 & & 380 & & 362 & & 292 & \\
\hline
\end{tabular}

Significance codes: ${ }^{* * * \prime} 0.01^{* * *} 0.05^{* \prime} 0.1$ 
Table 9: Exploring the relationship between technical efficiency of Italian arable farms with the lagged long term DAR, the contemporaneous short term DAR and other farm and farm management characteristics

\begin{tabular}{|c|c|c|c|c|c|c|c|c|c|c|c|c|}
\hline & 2009 & & 2010 & & 2011 & & 2012 & & 2013 & & 2014 & \\
\hline & Coef & S.E. & Coef & S.E. & Coef & S.E. & Coef & S.E. & Coef & S.E. & Coef & S.E. \\
\hline Lagged Long term DAR & -0.08 & 0.14 & -0.07 & 0.20 & 0.26 & 0.35 & -0.27 & 0.37 & -0.23 & 0.23 & 0.08 & 0.28 \\
\hline Contemporaneous Short term DAR & -0.08 & 0.07 & $-0.19 * *$ & 0.08 & 0.14 & 0.09 & -0.06 & 0.10 & 0.04 & 0.07 & -0.13 & 0.09 \\
\hline Share tangible assets & $-0.25 * * *$ & 0.03 & $-0.15 * * *$ & 0.04 & $-0.13 * * *$ & 0.03 & $-0.15 * * *$ & 0.03 & $-0.13 * * *$ & 0.03 & $-0.20 * * *$ & 0.03 \\
\hline Share farm labour & $-0.13 * * *$ & 0.04 & -0.05 & 0.05 & $-0.16^{* * *}$ & 0.04 & $-0.13 * * *$ & 0.04 & $-0.12 * * *$ & 0.05 & $-0.13 * *$ & 0.05 \\
\hline Education in years & $0.03 * * *$ & 0.01 & $0.03 *$ & 0.02 & 0.02 & 0.01 & 0.01 & 0.01 & 0.00 & 0.01 & 0.00 & 0.02 \\
\hline Share rented land & $\underline{\underline{-0.04 *}}$ & $\underline{\underline{0.02}}$ & $\underline{\underline{-0.06 * * *}}$ & $\underline{\underline{0.02}}$ & $\underline{\underline{-0.01}}$ & $\underline{\underline{0.02}}$ & $\underline{\underline{-0.05 * *}}$ & $\underline{\underline{0.02}}$ & $\underline{\underline{-0.04 *}}$ & $\underline{\underline{0.02}}$ & $\underline{\underline{-0.05 * *}}$ & $\underline{\underline{0.02}}$ \\
\hline Young & -0.02 & 0.02 & 0.01 & 0.02 & -0.01 & 0.02 & -0.01 & 0.02 & 0.00 & 0.03 & $0.05^{*}$ & 0.03 \\
\hline Elder & -0.02 & 0.01 & 0.00 & 0.02 & $0.02 *$ & 0.01 & -0.01 & 0.01 & $-0.06^{* * *}$ & 0.01 & -0.02 & 0.02 \\
\hline Female & $-0.06 * * *$ & 0.02 & $-0.05 * * *$ & 0.02 & -0.02 & 0.02 & $-0.03 * *$ & 0.02 & $-0.04 * *$ & 0.02 & -0.02 & 0.02 \\
\hline Shatented land & $0.04 *$ & 0.02 & $0.06 * * *$ & 0.02 & 0.01 & 0.02 & $0.05 * *$ & 0.02 & $0.04 *$ & 0.02 & $0.05 * *$ & 0.02 \\
\hline Farm in total LFA & $0.05 * *$ & 0.02 & -0.03 & 0.02 & $-0.04 * *$ & 0.02 & $-0.04 * *$ & 0.02 & $-0.03 *$ & 0.02 & -0.01 & 0.02 \\
\hline Region $N E$ & $0.23 * * *$ & 0.02 & $0.15^{* * *}$ & 0.02 & $0.15^{* * *}$ & 0.02 & $0.06^{* * *}$ & 0.02 & $0.08 * * *$ & 0.02 & $0.22 * * *$ & 0.02 \\
\hline Region Central & $0.06^{* * *}$ & 0.02 & $0.05^{*}$ & 0.02 & 0.03 & 0.02 & $0.06 * * *$ & 0.02 & $0.06^{* * *}$ & 0.02 & $0.10 * * *$ & 0.03 \\
\hline Region South & $-0.06 * *$ & 0.02 & $-0.12 * * *$ & 0.03 & $0.06^{* * *}$ & 0.02 & 0.03 & 0.02 & $0.04 *$ & 0.02 & $0.10 * * *$ & 0.03 \\
\hline Region Islands & $0.06^{*}$ & 0.04 & $-0.16^{* * *}$ & 0.05 & -0.03 & 0.04 & -0.02 & 0.05 & 0.00 & 0.05 & -0.02 & 0.05 \\
\hline Constant & $0.75 * * *$ & 0.05 & $0.69 * * *$ & 0.07 & $0.81 * * *$ & 0.06 & $0.87 * * *$ & 0.06 & $0.85^{* * *}$ & 0.06 & $0.86^{* * *}$ & 0.08 \\
\hline$N$ & 1002 & & 741 & & 953 & & 897 & & 899 & & 657 & \\
\hline Log Likelihood & 348 & & 255 & & 389 & & 381 & & 362 & & 292 & \\
\hline
\end{tabular}

Significance codes: '***’ $0.01^{(* * \prime} 0.05^{\prime * \prime} 0.1$ 
Number of holdings by main type of farming in Italy (2010 data)

\section{$381 \times 254 \mathrm{~mm}(150 \times 150 \mathrm{DPI})$}

